\title{
Morpho-Semantic of Predicate in Indonesian
}

\author{
Made Sri Satyawati \\ Faculty of Humanities, Udayana University, Denpasar, Indonesia \\ I Nyoman Kardana \\ Faculty of Letters, Warmadewa University, Denpasar, Indonesia \\ Dewa Ayu Kadek Claria \\ Faculty of Letters, Warmadewa University, Denpasar, Indonesia
}

\begin{abstract}
Semantically, a predicate is not always filled in by verbs. This study aims to discover and describe the predicate category and the number of arguments each predicate has in the Indonesian language. This study's data were taken from informants and the daily newspaper 'Bali Post'. The collected data were analyzed by applying deductive and inductive approaches. The result shows that Indonesian's predicate can be filled in by verb and non-verb categories: noun, adjective, preposition, and numeral. The predicate of the Indonesian sentences can be classified into the valency-one predicate, valency-two predicate, and valency-three predicate. Besides, there are several intransitive and transitive predicates in the Indonesian language, followed by a clause. Each of those finding is explained in detail in this article.
\end{abstract}

Index Terms - argument, predicate, semantic, valance, verb

\section{INTRODUCTION}

The syntactic and semantic aspects of a language are fascinating to study since they could show many distinct aspects of languages. A form of semantic and syntactic relations could be seen in the relation between propositions and sentences. A proposition is something or a thought in the human mind that can be realized in one or more sentences (Saeed, 1997). Each proposition expressed in a sentence(s) contains predicates, and noun phrases, often called arguments (Richards \& Schmidt, 2010). Predicate as a core element of a sentence can be studied based on syntactic and semantic approaches (Dixon, 2010). For instance, the predicate in English is syntactically always filled with verbs because English has copula verbs used as the predicate of a sentence when the sentence does not contain a full verb predicate. However, in other languages such as Indonesian, the predicate can also be filled by non-verb categories. Indonesian does not require copula verbs for sentences that do not contain any full verbs. In semantic studies, each proposition realized in a sentence contains one predicate and some nouns called arguments.

Indonesian has often become the research object as the national language and Indonesia's official language (Alwi et al., 1993). The studies of Indonesian sentences still focused on the syntactic study, which includes the study of syntactic functions of sentence elements and syntactic relations of the elements that build a sentence. Arka has discussed the typological, structural, and semantic issues of the expressions of tense-aspect-modality in Indonesian. It is demonstrated that the tense-aspect-modality in Indonesian is of the morphosemantic and contextual types (Arka, 2013). Referring to this reality, semantic studies on Indonesian sentences are critical since that semantic studies emphasize the meaning and the role of sentence elements, especially predicate, as the core element of a sentence (Akanya \& Omachonu, 2019).

Many studies have discussed the predicate of Indonesian sentences. However, most of the research still focused on studying predicates filled by verb categories, both intransitive and transitive verbs. In this study, Indonesian's predicate is analyzed based on a semantic theory that says predicate is filled by verbs and possibly by non-verb categories (Kreidler, 1998). Thus, this study aims to discover and describe the predicate category and the number of arguments each predicate has.

\section{LITERATURE REVIEW}

A predicate is a part of a sentence which states something about the subject and usually consists of a verb either with or without an object, complement, or adverb (Richards \& Schmidt, 2010). It conveys actions, processes, and states that refer to the subject (Bussman, 2006). As the central element of a sentence,, the predicate has a vital role in constructing a sentence (Demirezen, 2013). A predicate is not only filled by verbs, but it is also possibly filled by non-verb categories (Kreidler, 1998). In English and other languages such as Indonesian, predicate elements can be semantically verbs or non-verb categories, such as nouns, adjectives, prepositions, and numerals (Miozzo et al., 2014).

\section{METHOD}

Based on the data of the study, this research can be classified into a qualitative study. The researchers collected the 
data from the Bali Post daily newspaper written in Indonesian, published in June 2020. Besides, there are several data taken from informants who use Indonesian in their daily activities. Five informants were involved in this study. They were selected using a purposive sampling technique with a set of criteria. Those criteria include: the informant is minimum graduated from high school (so that they can speak Indonesian well, fluently, and correctly), speech organs are not disabled, active, and they tend to use Indonesian in everyday life, honest, physically and mentally healthy, male or female. Data were obtained by applying the observation method for both written data and oral data. The observation method was completed by recording technique and note-taking technique as well. The application of both techniques is very appropriate and useful in obtaining the required data. Furthermore, the collected data was analyzed qualitatively by applying a deductive and inductive approach, and the results were presented descriptively.

\section{FINDING AND DISCUSSION}

Indonesian sentences are broadly divided into sentences with verbal predicate and non-verbal predicate. Verbs that can be used as the predicate in Indonesian can be in basic form and derived forms. Therefore, a non-verbal predicate can be noun, adjective, preposition, adverbial, and number. The result of this study is supported by the previous study conducted by Gulö (2019) and Kartika et al. (2019), who found that the predicates in the Indonesian language can be in the form of verbs, adjectives, and nouns. Specifically, Moeljadi et al. (2016) found that there are three types of the basic copula in Indonesian, they are Noun Phrase (NP), Adjective Phrase (AP), and Prepositional Phrase (PP) that may occur without a copula verb. Verbless copula sentences with a nominal or adjectival predicate are also found in the Standard Arabic language (Alazzawie, 2016).

This study classifies the Indonesian predicates based on the number, types, and form of arguments that the predicates require or from verb valency classification (Čech et al., 2010). The Indonesian predicates can be categorized into the one-argument predicate, two-argument predicate, and three-argument predicate from the verb valency concept. This can be seen in the following analysis.

\section{Valency-one predicate}

Many sentences whose predicates require only one argument, commonly called the valency-one predicate, are found in Indonesian sentences. Semantically, the valency-one predicate sentences are classified into sentences with verbal predicate and sentences with a non-verbal predicate. This can be seen in the following examples and descriptions.

\section{Verb is a predicate}

Sentences with a one-argument predicate are generally filled with intransitive verbs (Matthews, 1981). Morphologically, intransitive verbs that function as predicates have various morphological forms. This can be seen in Table 1.

TABLE 1

EXAMPLES OF VERB As PREDICATE

\begin{tabular}{|c|c|c|}
\hline No & Examples & Meaning in English \\
\hline (1) & $\begin{array}{l}\text { Keberadaan pasar rakyat sebagai penggerak } \\
\text { perekonomian harus terus berjalan. }\end{array}$ & $\begin{array}{l}\text { The existence of the traditional market as the } \\
\text { driver of the economy must continue. }\end{array}$ \\
\hline (2) & $\begin{array}{l}\text { Meteran listrik itu sudah tidak berfungsi } \\
\text { lagi. }\end{array}$ & The electricity meter doesn't work anymore. \\
\hline (3) & $\begin{array}{l}\text { Teman-temannya sudah duduk. Dia sendiri } \\
\text { masih berdiri. }\end{array}$ & $\begin{array}{l}\text { His friends are already sitting. He himself is } \\
\text { still standing. }\end{array}$ \\
\hline (4) & $\begin{array}{l}\text { Tidak ada yang bisa memastikan kapan } \\
\text { pandemi Covid-19 berakhir. }\end{array}$ & $\begin{array}{l}\text { No one can be sure when the Covid-19 } \\
\text { pandemic ends. }\end{array}$ \\
\hline (5) & $\begin{array}{l}\text { Berita tentang kejadian di desa itu sudah } \\
\text { meluas }\end{array}$ & News about events in the village has spread. \\
\hline$(6)$ & Airnya sudah mendidih. & The water is boiling. \\
\hline (7) & $\begin{array}{l}\text { Pesawat yang dari Surabaya belum } \\
\text { mendarat }\end{array}$ & $\begin{array}{l}\text { The aircraft from Surabaya have not yet } \\
\text { landed. }\end{array}$ \\
\hline$(8)$ & Ancaman Covid-19 masih ada. & The Covid-19 threat still exists. \\
\hline
\end{tabular}

The data in Table 1 shows that the predicate filled by verbs berjalan 'to walk' in (1), berfungsi 'to function' in (2), berdiri 'to stand up in (3), berakhir 'to end' in (4), meluas 'to spread' in (5), mendidih 'to boil' in (6), mendarat 'to land' in (7), and $a d a$ 'to exist' in (8) are Indonesian intransitive verbs that only require one argument. The argument syntactically functions as the subject. Morphologically, the verbs in (1-4) are intransitive verbs with prefix ber- with noun base Jalan 'road' in (1), fungsi 'function' in (2), akhir 'the end' in (3); and pre-categorical base diri 'self' in (4). The verbs used in (5-8) are intransitive verbs with prefix me-with adjective base luas 'wide' in (5), pre category didih 'boil' in (6), and noun base darat 'the land' in (7). In (8), the predicate is filled by the base verb ada 'to exist'.

\section{Noun as Predicate}

Besides verbs, many other categories can function as the predicate of sentences with a one-argument predicate. One of them is a noun. Nouns as a predicate are also found in Azerbaijani and Turkic languages (Abbasova, 2014). Unlike English, Indonesian sentences with nouns as the predicate do not obligatorily require any copula verbs to complete the structure and the meaning of the sentences. The presence of copula verbs is optional. Indonesian sentences that show the one-argument predicate filled by nouns can be seen in Table 2 . 
TABLE 2

EXAMPLES OF NOUN AS PREDICATE

\begin{tabular}{|l|l|l|}
\hline No & \multicolumn{1}{|c|}{ Examples } & \multicolumn{1}{c|}{ Meaning in English } \\
\hline$(9)$ & Anak pertama saya dokter. & My first daughter is a doctor. \\
\hline$(10)$ & Istrinya juga dosen. & His wife is a lecturer as well. \\
\hline$(11)$ & Saat itu, saya masih mahasiswa. & At that time, I was a university student. \\
\hline
\end{tabular}

Table 2 shows that the predicates are filled in by the noun dokter 'doctor' in (9), dosen 'lecturer' in (10), and mahasiswa 'university student' in (11). The only argument the predicate has is the subject, such as anak pertama saya 'my first son/daughter' in (9), istrinya 'his wife' in (10), and saya 'I' in (11).

\section{Adjective as Predicate}

In addition to verbs and nouns, adjective also often functions as a predicate. Adjective as a predicate is also found in the Korean language since adjectives can fill the verb slot and function as a predicate (Yeo, 2008). In the Indonesian language, the adjective predicate requires only one core argument. Thus, the sentence constructed by the adjective predicate is identified as a sentence with a one-argument predicate. The examples to support this reality can be seen in Table 3.

TABLE 3

EXAMPLES OF ADJECTIVE As PREDICATE

\begin{tabular}{|c|l|l|}
\hline No & \multicolumn{1}{|c|}{ Examples } & \multicolumn{1}{c|}{ Meaning in English } \\
\hline$(12)$ & Bisnis akomodasi juga sangat lesu. & $\begin{array}{l}\text { The accommodation business does not run } \\
\text { either. }\end{array}$ \\
\hline$(13)$ & Pasar Kumbasari Pagi masih buka. & Kumbasari Morning Market is still open. \\
\hline$(14)$ & Adiknya jangan diganggu. Dia sakit. & Don't bother her sister. She is sick. \\
\hline$(15)$ & Lokasi tersebut benar-benar steril. & The location is really sterile. \\
\hline$(16)$ & $\begin{array}{l}\text { Kemana dialihkan, urgensinya harus } \\
\text { jelas. }\end{array}$ & Where it is diverted, its urgency must be clear. \\
\hline$(17)$ & Adiknya takut kalau ada gempa. & His sister is afraid of earthquakes. \\
\hline
\end{tabular}

Table 3 shows that the predicate is filled by adjective phrase sangat lesu 'very weak' in (12), masih buka 'still open' in (13), benar-benar steril 'completely sterile' at (15), harus jelas 'must be clear' in (16), and adjective sakit 'sick' in (14), takut 'scare' in (17). All the adjective predicates require one argument that functions as the subject of the sentence. Therefore, the adjectival predicate constructions (12-17) are classified as one-argument predicate sentences.

\section{Numeral as Predicate}

The semantic approach analysis of the Indonesian sentences may also admit numeral as the predicate. Data showing numeral as the predicate of sentence can be seen in Table 4.

TABLE 4

EXAMPLES OF NUMERAL AS PREDICATE

\begin{tabular}{|c|l|l|}
\hline No & \multicolumn{1}{|c|}{ Examples } & \multicolumn{1}{|c|}{ Meaning in English } \\
\hline$(18)$ & $\begin{array}{l}\text { Saudaranya tiga, satu laki-laki dan dua } \\
\text { perempuan. }\end{array}$ & His siblings are three, one male and two female. \\
\hline$(19)$ & $\begin{array}{l}\text { Mahasiswa yang hadir hari ini tujuh puluh. } \\
\text { Students who are present today are seventy. }\end{array}$ & His portion is only half. \\
\hline$(20)$ & $\begin{array}{l}\text { Bagiannya hanya setengah. } \\
\text { tingkat Penghunian Kamar khususnya hotel } \\
\text { sekitar tiga persen. }\end{array}$ & $\begin{array}{l}\text { Room Occupancy Rates especially star-rated hotels } \\
\text { in Bali in April 2020 were only around three } \\
\text { percent. }\end{array}$ \\
\hline
\end{tabular}

In (18), the predicate is filled in by numeral tiga 'three', in (19) the predicate is filled in by numeral tujuh puluh 'seventy, in (20), the predicate is filled in by setengah 'half', and in (21) the predicate is filled in by numeral tiga persen 'three per cent. The predicates filled in by the numerals have a subject argument, namely saudaranya 'his/her sibling in (18), mahasiswa yang hadir hari ini 'university students who come today' in (19), bagiannya 'his part' in (20), and tingkat penghunian kamar....'Room occupancy rate...' in (21). Those subjects are the only argument the numeral predicates have in the construction.

\section{Valency-Two Predicate}

Many sentences whose predicate has two mandatory arguments are found in the Indonesian language. The sentence with the two-argument predicate in Indonesian is still distinguished between the verb and non-verb predicate. This can be seen in the following analysis.

\section{Verb as the Predicate}

All languages have lexical categories of nouns and verbs (Polinsky \& Magyar, 2020). Verbs generally function as a predicate, while nouns function as arguments (Luuk, 2010; Matthews, 1981). In Indonesian, predicate verbs can be both intransitive and transitive verbs. The use of both verbs can be seen in the following analysis. As presented in the previous description, intransitive verb predicates have one argument functioning as a subject. However, based on the collected data, intransitive verb predicate may require two arguments, one core argument and one oblique core argument. The intransitive verb in Indonesian has various morphological forms. That is seen in Table 5. 
TABLE 5

EXAMPLES OF VERB As PREDICATE

\begin{tabular}{|c|c|c|}
\hline No & Examples & Meaning in English \\
\hline (22) & $\begin{array}{l}\text { Kapolres berpesan kepada personelnya agar } \\
\text { tetap semangat menjalankan tugas-tugas } \\
\text { mulai ini. }\end{array}$ & $\begin{array}{l}\text { The police chief advised his personnel to keep the } \\
\text { spirit of carrying out the tasks starting from this. }\end{array}$ \\
\hline (23) & $\begin{array}{l}\text { Bapak Kapolres sempat ngobrol dengan } \\
\text { lansia itu. }\end{array}$ & Mr. Police Chief had a chat with the elderly. \\
\hline (24) & $\begin{array}{l}\text { Lebih lanjut Rai Mantra berharap beragam } \\
\text { upaya dan keberhasilan Satgas Covid-19 } \\
\text { Lingkungan Banjar Ujung Kesiman ini } \\
\text { dapat menjadi contoh. }\end{array}$ & $\begin{array}{l}\text { Furthermore, Rai Mantra hopes that the various } \\
\text { efforts and successes of the Task Force for Covid- } \\
19 \text { at Banjar Ujung Kesiman can be an example. }\end{array}$ \\
\hline$(25)$ & $\begin{array}{l}\text { Pandemi Covid-19 ini terus berimbas pada } \\
\text { penurunan kemampuan ekonomi } \\
\text { masyarakat. }\end{array}$ & $\begin{array}{l}\text { The Covid-19 pandemic continues to impact the } \\
\text { decline in peoples economic capacity. }\end{array}$ \\
\hline (26) & $\begin{array}{l}\text { Kewaspadaan masyarakat merupakan suatu } \\
\text { keharusan saat ini. }\end{array}$ & Public awareness is a must now. \\
\hline (27) & $\begin{array}{l}\text { Mulai } 9 \text { Juni } 2020, \text { Dandrem 163/Wira Satya } \\
\text { berpangkat Brigjen. }\end{array}$ & $\begin{array}{l}\text { Starting } 9 \text { June } 2020 \text {, Dandrem } 163 \text { / Wira Satya } \\
\text { holds the rank of Brigjen. }\end{array}$ \\
\hline (28) & $\begin{array}{l}\text { Orang tua itu selalu bertindak hati-hati dan } \\
\text { perlahan-lahan dalam mengerjakan sesuatu. }\end{array}$ & $\begin{array}{l}\text { The old man always acts carefully and slowly in } \\
\text { doing something. }\end{array}$ \\
\hline (29) & $\begin{array}{l}\text { Efek yang ditimbulkan berdampak pada } \\
\text { semua sektor. }\end{array}$ & The resulting effects affect all sectors. \\
\hline
\end{tabular}

Data above show that the predicate is filled in by intransitive verbs such as berpesan 'to advise' in (22), ngobrol 'to chat' in (23), berharap 'to hope' in (24), berimbas 'to impact' in (25), merupakan 'to be' in (26), berpangkat 'to hold the rank of ' in (27), bertindak 'to act' in (28), and berdampak 'to impact' in (29). The verbs require two arguments, namely one core argument and one oblique core argument (P. R. Kroeger, 2005). The core argument is the noun phrase preceding verbs functioning as the predicate subject. Meanwhile, the oblique core argument is the argument in the form of a prepositional phrase, adverbial, and noun phrase directly following the verbs. The arguments function as the verb complement (Baker, 2003). The intransitive verbs that require oblique core argument like in (22-29) become one of this study's prominences. In other languages, this phenomenon may be rarely found.

In addition to the intransitive verbs described above, many transitive verbs are also used in Indonesian sentences. It means that the transitive verbs require two core arguments in the sentence. Therefore, transitive verbs often refer to two-argument predicates (Valin \& LaPolla, 2001). This can be seen in Table 6.

TABLE 6

EXAMPLES OF VERB As PREDiCATE

\begin{tabular}{|c|l|l|}
\hline No & \multicolumn{1}{|c|}{ Examples } & \multicolumn{1}{|c|}{ Meaning in English } \\
\hline$(30)$ & $\begin{array}{l}\text { Sektor pertanaian tidak pernah jenuh menyerap } \\
\text { tenaga kerja. }\end{array}$ & $\begin{array}{l}\text { The agricultural sector is never saturated in } \\
\text { absorbing labour. }\end{array}$ \\
\hline$(31)$ & Bali harus memiliki sebuah pasar induk. & Bali must have a wholesale market. \\
\hline$(32)$ & $\begin{array}{l}\text { BPD Bali mendukung komitmen Pemerintah } \\
\text { Daerah Bali dan pelaku UMKM menuju } \\
\text { kemandirian pangan Bali. }\end{array}$ & $\begin{array}{l}\text { The local bank of Bali supports the commitment } \\
\text { of the Bali Regional Government and the Small } \\
\text { and Middle Economic Industry to Balis food } \\
\text { independence. }\end{array}$ \\
\hline (33) & $\begin{array}{l}\text { Komisi IV DPRD Bali sudah menggelar rapat } \\
\text { dengan Dinas Pendidikan, Kepemudaan dan } \\
\text { Olah Raga Provinsi Bali. }\end{array}$ & $\begin{array}{l}\text { Commission IV of the Bali DPRD has held a } \\
\text { meeting with the Bali Provincial Office of } \\
\text { Education, Youth and Sports. }\end{array}$ \\
\hline (34) & $\begin{array}{l}\text { Wali Kota Rai Mantra memberikan apresiasi } \\
\text { kepada seluruh Satgas Covid-19 }\end{array}$ & $\begin{array}{l}\text { The Mayor, Rai Mantra gave his appreciation to } \\
\text { the entire Covid-19 Task Force. }\end{array}$ \\
\hline
\end{tabular}

Table 6 shows that the predicate of the above sentences is filled in by verb menyerap 'to absorb' in (30), memiliki 'to have' in (31), mendukung 'to support' in (32), menggelar 'to carry out' in (33), and memberikan 'to give' in (34). The transitive verb requires two core arguments, which syntactically function as subjects and objects. Noun phrases that precede the verb, namely sektor pertanian 'the agricultural sector', Bali 'Bali', BPD Bali 'Local Bank of Bali', Komisi IV DPRD Bali 'Bali Commission IV, and Wali Kota Rai Mantra 'the mayor Rai Mantra' are the subject of the sentence and noun phrases that immediately follow the verb, such as tenaga kerja 'labor', sebuah pasar induk 'a wholesale market', komitmen pemerintah daerah Bali 'Bali Regional Government commitment', rapat 'meeting, and apresiasi 'appreciation' are the object of the verb. Meanwhile, other elements such as menuju kemandirian pangan Bali 'towards food independence' in (32), dengan Dinas Pendidikan, Kepemudaan dan Olah Raga Provinsi Bali 'with the Bali Provincial Office of Education, Youth and Sports' in (33), and kepada seluruh Satgas Covid-19 'to the all Covid-19 Task Force' in (34) are identified as periphery.

\section{Preposition as Predicate}

For sentences with a two-argument predicate, the predicate can also be filled in by a preposition. The examples of sentences in which the predicate is semantically filled by preposition are shown in Table 7. 
TABLE 7

EXAMPLES OF PREPOSITION AS PREDICATE

\begin{tabular}{|c|l|l|}
\hline No & \multicolumn{1}{|c|}{ Examples } & \multicolumn{1}{|c|}{ Meaning in English } \\
\hline$(35)$ & Sekarang ibu di kampus & 'Now mother is at the campus. \\
\hline$(36)$ & Ibu saya ke pasar setiap hari minggu & 'My mother goes to the market every Sunday' \\
\hline (37) & $\begin{array}{l}\text { Suaminya dari Kintamani tapi sudah lama } \\
\text { tinggal di Denpasar. }\end{array}$ & $\begin{array}{l}\text { 'Her husband is from Kintamani, but he has been } \\
\text { living for many years in Denpasar' }\end{array}$ \\
\hline
\end{tabular}

The declarative sentences above use prepositions as the predicate. The prepositions $d i$ 'at' in (35), $k e$ 'to' in (36), and dari 'from' in (37) are semantically identified as the central element of the sentences. The prepositions require two arguments that function as subject and complement. The subject arguments of the sentences are ibu 'mother', ibu saya 'my mother', and suaminya 'her husband', while the arguments filled in by noun kampus 'campus', pasar 'market', and Kintamani 'Kintamani' together with the preposition create prepositional phrases functioning as adverbial showing place. Other elements such as setiap hari minggu 'every Sunday' in (36) is an adverbial phrase showing time and tapi sudah lama tinggal di Denpasar 'but has been living in Denpasar for a long time' in (37) are adverbial phrases showing the time that are classified as periphery.

\section{Adverbial as Predicate}

Besides prepositions as in the examples (39-41), Indonesian also has adverbials as the predicate of sentences. According to Dixon (2005), adverbial elements can refer to space, time, frequency or degree, and manner of an activity or state. They can comprise a, a phrase, or a clause. Adverbial phrases are generally introduced by a preposition, although there are exceptions, e.g., last week, many times, this way. The examples of adverbial used as the predicate of the Indonesian sentences can be seen in Table 8 .

TABLE 8

EXAMPLES OF ADVERBIAL AS PREDICATE

\begin{tabular}{|c|l|l|}
\hline No & \multicolumn{1}{|c|}{ Examples } & \multicolumn{1}{c|}{ Meaning in English } \\
\hline$(38)$ & $\begin{array}{l}\text { Tingkat Penghunian Kamar hotel berbintang } \\
\text { umumnya selalu di atas 50 persen. }\end{array}$ & $\begin{array}{l}\text { The occupancy rate of starred hotel rooms is } \\
\text { commonly always above 50 per cent. }\end{array}$ \\
\hline$(39)$ & Dompet saya di atas meja. & My wallet is on the table. \\
\hline$(40)$ & Tempatnya di belakang Gedung Kesenian. & The venue is behind the Arts Building. \\
\hline$(41)$ & Mahasiswa sudah di dalam kelas. & Students are already in class. \\
\hline
\end{tabular}

The predicate of the above sentences is filled in by complex preposition di atas 'above' in (38-39), di belakang 'behind' in (40), and di dalam 'inside' in (41). In the examples (38-41), there are two arguments, namely Tingkat Penghunian Kamar hotel berbintang 'The Occupancy Rate of starred hotel rooms' and 50 persen '50 per cent' in (38), dompet saya 'my wallet' and meja 'table' in (39), tempatnya 'the venue' and gedung kesenian 'art building' in (40), mahasiswa 'university students' and kelas 'classroom' in (41). The two arguments in each sentence become mandatory, and the complex preposition strictly ties them.

\section{Valency-Three Predicate}

In Indonesian, there are some sentences whose predicates require three arguments, and all three arguments are direct core arguments. This can be seen in Table 9.

TABLE 9

EXAMPLES OF VALENCY-THREE PREDICATE As PREDICATE

\begin{tabular}{|c|l|l|}
\hline No & \multicolumn{1}{|c|}{ Examples } & \multicolumn{1}{|c|}{ Meaning in English } \\
\hline$(42)$ & Dia membelikan adiknya baju baru. & 'He bought his younger brother new clothes.' \\
\hline$(43)$ & $\begin{array}{l}\text { Bibinya menyewakannya pakaian untuk } \\
\text { menari. }\end{array}$ & 'Her aunt rented her clothes for dancing. \\
\hline$(44)$ & Dia membuatkan adiknya layangan. & 'He made his younger brother a kite'. \\
\hline
\end{tabular}

From the Table 9, it is known that the predicate is filled in by derived verbs such as membelikan 'to buy' in (42), menyewakan 'to rent' in (43), and membuatkan 'to make' in (44). The suffix -kan in Indonesian has two very different modes of operation in the grammar. These two modes can be identified by the syntactic (monotransitive vs ditransitive) and semantic (theme vs benefactive) patterns that they create (P. Kroeger, 2007). The verbs require three arguments, which syntactically function as a subject, indirect object, and direct object (S, IO, DO). The presence of the three arguments is caused by suffixes -an. This suffix is well-known as a suffix that can create valencies, e.g., from intransitive to transitive and transitive to bitransitive. It can be proven that if the suffix -an is removed, then the verbs become membeli 'to buy', menyewa 'to rent', and membuat 'to make', which only require two arguments so that they belong to transitive verbs. Meanwhile, the verbs like membelikan 'to buy', menyewakan 'to rent', and membuatkan 'to make' as in (42-44) are included in the bitransitive verbs. Thus, the suffix -an in Indonesian functions to increase valency- from valency two to valency three. Sentences (42-44) derives from (45-47) in Table 10 below. 
TABLE 10

EXAMPLES OF VALENCY-THREE PREDICATE As PREDICATE

\begin{tabular}{|c|c|c|}
\hline No & Examples & Meaning in English \\
\hline$(45)$ & $\begin{array}{l}\text { Dia membeli baju untuk adiknya kemarin } \\
\text { malam }\end{array}$ & He bought clothes for his younger brother last night. \\
\hline (46) & $\begin{array}{l}\text { Bibinya menyewa pakaian untuk menari } \\
\text { untuknya. }\end{array}$ & Her aunt rented clothes for dancing for her. \\
\hline$(47)$ & Dia membuat layangan untuk adiknya. & He made a kite for his younger brother. \\
\hline
\end{tabular}

The verb membeli 'to buy in (45), menyewa 'to rent' in (46), and membuat 'to make' in (47) only need two arguments that function as subject and object. Prepositional phrases in those sentences belong to the oblique core argument. And the oblique argument can be promoted into core argument by the suffix -an like in (42-44).

\section{Verbs Followed by a Clause}

Verb predicate in Indonesian can sometimes be followed by a word, a phrase, and a clause. Predicate followed by a word or a phrase has been discussed in the sub-chapter before. Based on the data, a predicate followed by a clause can be seen in Table 11.

TABLE 11

EXAMPLES OF FOLLOWED By A CLAUSE

\begin{tabular}{|c|l|l|}
\hline No & \multicolumn{1}{|c|}{ Examples } & \multicolumn{1}{c|}{ Meaning in English } \\
\hline$(48)$ & $\begin{array}{l}\text { Dewa Sadguna menyarankan sudah saatnya } \\
\text { pertanian di Bali dimoderninsasi. }\end{array}$ & $\begin{array}{l}\text { Dewa Sadguna suggested that it was time for } \\
\text { agriculture in Bali to be modernized. }\end{array}$ \\
\hline$(49)$ & $\begin{array}{l}\text { Achmad Yurianto menambahkan bahwa untuk } \\
\text { yang sehat ada penambahan 591 pasien sembuh } \\
\text { sehingga totalnya menjadi 10.498 pasien. }\end{array}$ & $\begin{array}{l}\text { Achmad Yurianto added that for healthy people, there } \\
\text { were 591 additional patients recovered, bringing the } \\
\text { total to 10,498 patients. }\end{array}$ \\
\hline$(50)$ & $\begin{array}{l}\text { Pangdam IX Udayana mengatakan almarhum } \\
\text { merupakan seorang penerbang pelatih. }\end{array}$ & $\begin{array}{l}\text { Pangdam IX Udayana said the deceased was a pilot } \\
\text { trainer. }\end{array}$ \\
\hline (51) & $\begin{array}{l}\text { Kepala Bappeda ini menyatakan akan } \\
\text { mendedikasikan ilmu yang diperolehnya untuk } \\
\text { membangun bangsa melalui kesehariannya } \\
\text { sebagai birokrat di Pemkab Badung. }\end{array}$ & $\begin{array}{l}\text { The Head of Bappeda stated that he would dedicate } \\
\text { the knowledge he obtained to build the nation through } \\
\text { his daily life as a bureaucrat in the Badung Regency } \\
\text { Government. }\end{array}$ \\
\hline $\begin{array}{l}\text { Gung Nik menjelaskan bahwa sinergi terus } \\
\text { dilaksanakan mulai dari Kelurahan, Desa Adat, } \\
\text { Banjar Adat, STT, hingga PKK. }\end{array}$ & $\begin{array}{l}\text { Gung Nik explained that the synergy continued to be } \\
\text { carried out starting from the Administrative village, } \\
\text { traditional village, youth organization, to women } \\
\text { organization. }\end{array}$ \\
\hline (53) & $\begin{array}{l}\text { Dia berharap segala aturan pemerintah mesti } \\
\text { ditaati. }\end{array}$ & $\begin{array}{l}\text { He hopes that all government regulations must be } \\
\text { obeyed. }\end{array}$ \\
\hline
\end{tabular}

The complex sentences (48-53) each contain one main clause and one embedded clause. The predicate of the main clause is filled by transitive verb menyarankan 'to suggest' in (48), menambahkan 'to add' in (49), mengatakan 'to say' in (50), menyatakan 'to state' in (51), menjelaskan 'to explain' in (52), and intransitive verb berharap 'to hope' in (53). All the verbs are followed by a clause that functions as an object or a complement.

\section{CONCLUSION}

Based on the semantic analysis done in the discussion, it is known that predicate in Indonesian is divided into verbal and non-verbal predicates. Based on the number of arguments they have, the predicates are classified into the oneargument predicate, two-argument predicate, and three-argument predicate. This study is limited to the types of Indonesian predicate from the morpho-semantic theory. It means that this study is done to enrich the linguistic knowledge of the Indonesian language. Thus, the results of this study can be used in the applied linguistics field, especially in teaching English in the Indonesian context, by conducting further research that compares the Indonesian predicate to the English predicate.

\section{ACKNOWLEDGEMENTS}

This research was supported by the grant from Universitas Warmadewa Denpasar academic year 2019/2020.

\section{REFERENCES}

[1] Abbasova, E. (2014). The issues of modality in the Azerbaijani linguistics and study of Turkic language (Turkology). Procedia - Social and Behavioral Sciences, 152, 1252-1255. https://doi.org/10.1016/j.sbspro.2014.09.360

[2] Akanya, J., \& Omachonu, C. G. (2019). Meaning and semantic roles of words in context. International Journal of English Language and Linguistics Research, 7(2), 1-9.

[3] Alazzawie, A. (2016). An agree-based account of verbless copula sentences in Standard Arabic. Ampersand, 3, $151-162$. https://doi.org/10.1016/j.amper.2016.08.001

[4] Alwi, H., Dardjowidjojo, S., Lapoliwa, H., \& Moeliono, A. M. (1993). Tata bahasa baku Bahasa Indonesia. Perum Balai Pustaka. 
[5] Arka, I. W. (2013). On the typology and syntax of TAM in Indonesian. Tense, Aspect, Mood and Evidentiality in Languages of Indonesia, 23-40.

[6] Baker, M. C. (2003). Lexical Categories: Verbs, Nouns, and Adjectives. Cambridge University Press.

[7] Bussman, H. (2006). Routledge Dictionary of Language and Linguistics.

[8] Čech, R., Pajas, P., \& Mačutek, J. (2010). Full valency: Verb valency without distinguishing complements and adjuncts. Journal of Quantitative Linguistics, 17(4), 291-302. https://doi.org/10.1080/09296174.2010.512162

[9] Demirezen, M. (2013). The recognition of extended simple sentences as a teaching writing problem. Procedia - Social and Behavioral Sciences, 70, 560-566. https://doi.org/10.1016/j.sbspro.2013.01.093

[10] Dixon, R. M. W. (2005). A Semantic Approach to English Grammar. Oxford University Press.

[11] Dixon, R. M. W. (2010). Basic Linguistic Theory. Oxford University Press.

[12] Gulö, I. (2019). Predicates of Indonesian and English simple sentences. TEKNOSASTIK, $15(2), \quad 76$. https://doi.org/10.33365/ts.v15i2.102

[13] Kartika, D., Edel, E. E., \& Atmazaki. (2019). Grammatical comparison of noun: Indonesian and Japanese. Humanities \& Social Sciences Reviews, 7(5), 522-527. https://doi.org/10.18510/hssr.2019.7560

[14] Kreidler, C. W. (1998). Introducing English Semantics. Routledge.

[15] Kroeger, P. (2007). Morphosyntactic vs. morphosemantic functions of Indonesian-kan. Architecture, Rules, and Preferences: Variations on Themes of Joan Bresnan, 1(1992), 229-251. http://gial.edu/personnel/kroeger/Indon-2-kan-JB-prepub.pdf

[16] Kroeger, P. R. (2005). Analyzing Grammar: An Introduction. Cambridge University Press.

[17] Luuk, E. (2010). Nouns, verbs and flexibles: implications for typologies of word classes. Language Sciences, 32(3), $349-365$. https://doi.org/10.1016/j.langsci.2009.02.001

[18] Matthews, P. H. (1981). Syntax. Cambridge University Press.

[19] Miozzo, M., Rawlins, K., \& Rapp, B. (2014). How verbs and non-verbal categories navigate the syntax/semantics interface: Insights from cognitive neuropsychology. Cognition, 133(3), 621-640. https://doi.org/10.1016/j.cognition.2014.08.004

[20] Moeljadi, D., Bond, F., \& da Costa, L. M. (2016). Basic copula clauses in Indonesian. Proceedings of the Joint 2016 Conference on Head-Driven Phrase Structure Grammar and Lexical Functional Grammar, 442-456.

[21] Polinsky, M., \& Magyar, L. (2020). Headedness and the lexicon: The case of verb-to-noun ratios. Languages, 5(1), 9. https://doi.org/10.3390/languages5010009

[22] Richards, J. C., \& Schmidt, R. W. (2010). Longman Dictionary of Language Teaching and Applied Linguistics (Fourth Edi). Longman.

[23] Saeed, J. I. (1997). Semantics. Blackwell Publishers Inc.

[24] Valin, R. D. Van, \& LaPolla, R. J. (2001). Syntax: structure, meaning, and function (Cambridge Textbooks in Linguistics). In Journal of Linguistics (Vol. 37, Issue 3, pp. 627-649). Cambridge University Press (\{CUP\}). https://doi.org/10.1017/s0022226701291361

[25] Yeo, S. (2008). Morphosyntax of predicates and syntactic categories in Korean. Lingua, 118(3), 332-369. https://doi.org/10.1016/j.lingua.2007.07.001

Made Sri Satyawati is a lecturer at the Indonesian Department, Faculty of Humanities, Udayana University, Bali, Indonesia. She obtained her Master Degree in Linguistics from Padjadjaran University, Bandung, Indonesia in 1999, and she got her Doctorate Degree in Linguistics from Udayana University in 2010. Her research interest is linguistics, and she has conducted some research on syntax, typology, and semantics. Her publications involve study on Indonesian language and some local languages in Eastern Indonesia. She has supervised many bachelor papers, theses and doctorate dissertations. She has also participated as a guest and invited speaker in several national and international seminars.

I Nyoman Kardana is a professor in Linguistics at Faculty of Letters Warmadewa University, Bali Indonesia. He received his Master Degree in Linguistics from Padjadjaran University, Bandung, Indonesia in 1998. He obtained his Doctorate Degree in Linguistics from Udayana University, Bali, Indonesian 2004. He has been doing some researches related to the topics about morphosyntax, semantics, and eco-linguistics. He has supervised many papers, theses and doctorate dissertations. He has also written a lot of articles published in national and international journals. He has participated in many national and international seminars as well.

Dewa Ayu Kadek Claria is one of the lecturers at the English Department, Faculty of Letters Warmadewa University, Bali Indonesia. She received her Master Degree in Linguistics from Warmadewa University, Denpasar, Indonesia in 2015. Her research interest involves a lot of Discourse Analysis, Systemic Functional Linguistics and Eco-linguistics. She has participated in several local, national, and international seminars and workshops. 